\title{
Giant clams of Andrew Bay in Rakhine coastal region of Myanmar
}

\begin{abstract}
Giant clams of genus Tridacna Bruguière, 1797, collected from Andrew Bay (Lat. $18^{\circ} 25^{\prime}$ N, Long. $94^{\circ} 15^{\prime}$ E) of the Rakhine Coastal Region from 2014 to 2018, had been identified as Crocus giant clam T. crocea Lamarck, 1819; Giant clam T. gigas (Linnaeus, 1758); Elongate giant clam T. maxima (Röding, 1798) and Fluted giant clam T. squamosa Lamarck, 1819, based on living shells and some conchological features. Although T. crocea Lamarck, 1819 was characterized by its triangular-ovate in outline, T. gigas (Linnaeus, 1758) was recognized by its subovate to fan-shaped in outline, T. maxima (Röding, 1798) was followed by its elongate-ovate to somewhat triangular in outline and T. squamosa Lamarck, 1819 was identified by its semi-circular in outline. The comparison on different characteristics of Tridacna spp. from Andrew Bay was provided in details.
\end{abstract}

Keywords: Giant clams, Tridacnidae, conchological features, Andrew Bay, Rakhine coastal region, Myanmar
Volume 7 Issue 6 - 2018

\author{
Naung Naung Oo \\ Department of Marine Science, Mawlamyine University, \\ Myanmar
}

\begin{abstract}
Correspondence: Naung Naung Oo,Assistant Lecturer, Department of Marine Science, Mawlamyine University, Myanmar, Email naungnaungoomarine@gmail.com
\end{abstract}

Received: December 16,2018 | Published: December 27, 2018

\section{Introduction}

The Rakhine Coastal Region has a coastline stretching about $740 \mathrm{~km}$ facing the Bay of Bengal which possesses marine fishery resources. Andrew Bay (Lat. $18^{\circ} 25^{\prime} \mathrm{N}$, Long. $94^{\circ} 15^{\prime} \mathrm{E}$ ) is one of the unique ecosystem in Rakhine Coast where is a huge habitat with rich biodiversity. The seashells diversity holds significant social, economic and cultural values for the local population. Giant clams (Tridacnidae) are conspicuous bivalves that live in close association with coral reefs throughout the Indo-Pacific 1. Tridacnidae are traditionally harvested throughout the tropical western Pacific for their shell and highly prized meat. All the soft parts are edible except for the kidney which may accumulate arsenic and heavy metals. Widespread overfishing and deterioration of coral environments in some areas have frequently caused a decline of the clam populations in the recent past years 2. Since the early 1980s, 4 species of tridacnids were reported in Myanmar: T. crocea Lamarck, 1819, T. elongate (Lamarck, 1819), T. gigas (Linnaeus, 1758) and T. squamosa Lamarck, 1819 3. Naung Naung Oo and Lwin Lwin 4 described only species of Fluted giant clam Tridacna squamosa Lamarck, 1819 and reported a new record of Andrew Bay. Much information such as their biology, distribution pattern, habitat preferences and habitat range were still remained unknown. The objectives of current study are 1) to identify the diversified species of giant clams; and 2) to investigate the species distribution of giant clams population in their natural habit. This information is very important for conservation and for better management of tridacnids.

\section{Materials and methods}

Live specimens of giant clams were collected by snorkeling from intertidal and shallow subtidal areas of Pearl I., Kathit I., Thabyu Gyaing, Ponenyat Gyaing, Kyauk pone gyi hmaw, Kwinwine Gyaing and Maung shwe lay Gyaing around the Andrew Bay (Figure 1) during the field trip in 2014-2018. All collections were preserved in $10 \%$ formalin in seawater. The epifaunas were removed by soaking the shells in a solution of caustic soda and then cleaned, washed, dried, and ready for storage, they are lightly rubbed with a small amount of oil applied with a brush to make them fresh-looking in a slight luster to the surface, and aid in presenting the delicate colouring for further study. All voucher specimens were deposited at the Museum of the Department of Marine Science, Mawlamyine University (MLM.MS).

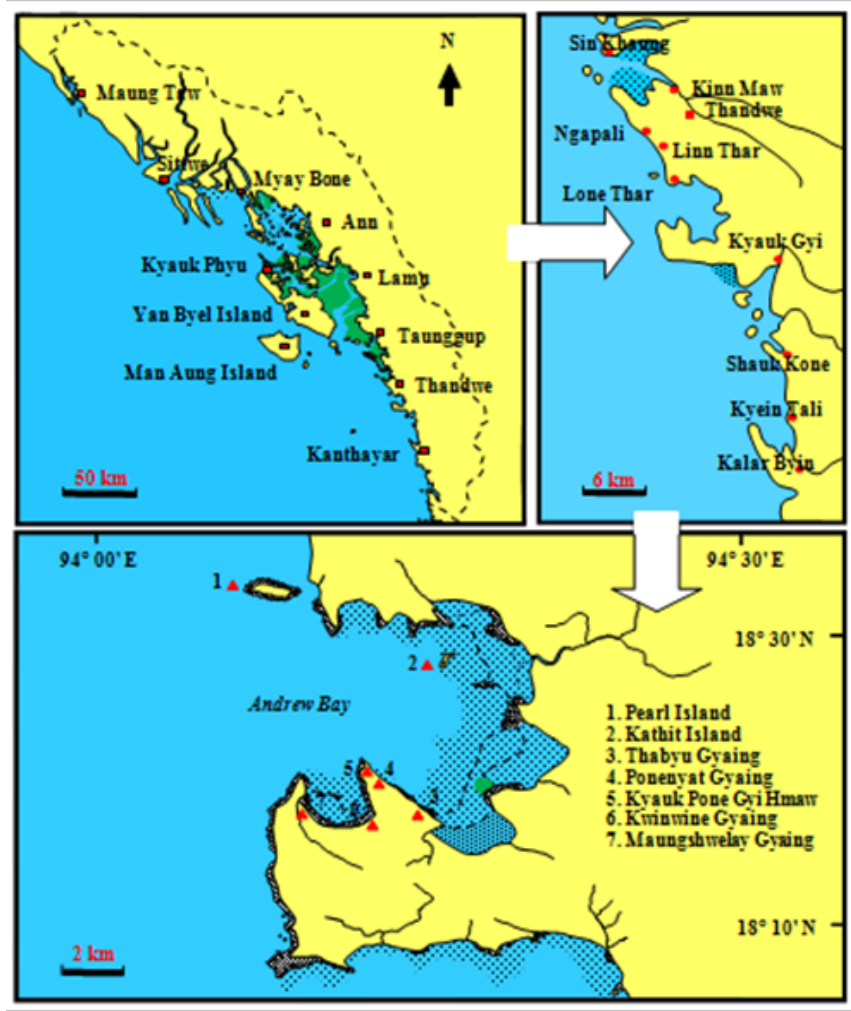

Figure I Map showing the sample collection of Andrew Bay.

\section{Results and discussion}

The morphology and distribution of tridacnids in Andrew Bay is given. Altogether 7 fringing and patch reefs areas were surveyed. From the observed (intertidal and subtidal) 98 giant clams were found, comprising 4 species: Tridacna crocea $(\mathrm{n}=22$, size range $=92$ 
to $150 \mathrm{~mm}$ ), T. gigas $(\mathrm{n}=19$, size range $=112$ to $180 \mathrm{~mm}), T$. maxima $(\mathrm{n}=34$, size range $=96$ to $198 \mathrm{~mm})$ and $T$. squamosa $(\mathrm{n}=23$, size range $=140$ to $380 \mathrm{~mm}$ ). Systematic and species status are based on Poutiers and WoRMS 2,5 in detailed (Table 1) (Figure 2).

Table I Systematic of giant clams in Andrew Bay

$\begin{array}{lll}\text { Phylum } & : & \text { Mollusca Linnaeus, I758 } \\ \text { Class } & : & \text { Bivalvia (=Pelecypoda) Linnaeus, I758 } \\ \text { Order } & : & \text { Cardiida Ferussac, I822 } \\ \text { Family } & : & \text { Tridacnidae Lamarck, I819 (=Cardiidae Lamarck, I809) } \\ \text { Genus } & : & \text { Tridacna Bruguière, I797 } \\ & \text { I } & \text { T. crocea Lamarck, I819 } \\ & 2 & \text { T. gigas (Linnaeus, I758) } \\ \text { Species } & 3 & \text { T. maxima (Röding, I798) } \\ & 4 & \text { T. squamosa Lamarck, I8I9 }\end{array}$
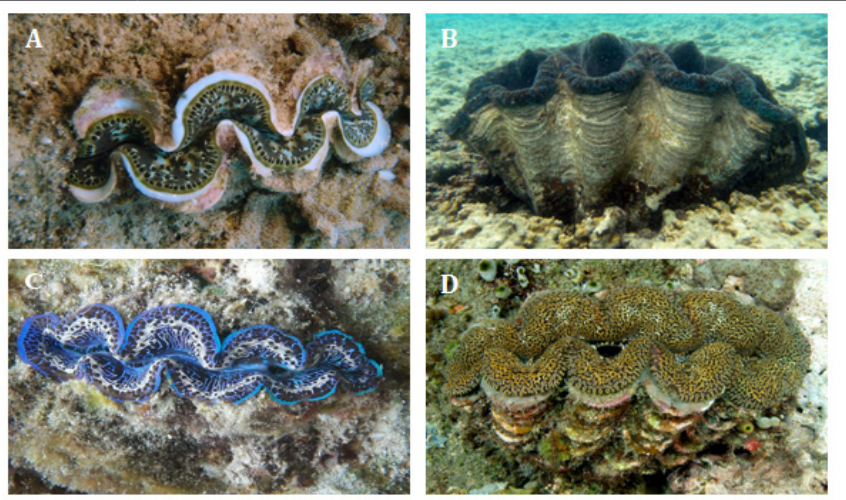

Figure 2 (A- D): Giant clams: A) Tridacna crocea Lamarck, 1819, B) T. gigas (Linnaeus, I758), C) T. maxima (Röding, I 798), D) T. squamosa Lamarck, I8I9.

Key to the species of tridacnids in Andrew Bay

1.a. Shell is triangular-ovate in outline
1.b. Shell is subovate to fan-shaped in outline

2.a. Umbones usually near mid length of shell ..$T$. gigas

2.b. Umbones markedly anterior in position

3.a. Radial folds bearing closely set, erect but low T. maxima

3.b. Radial folds bearing large, erect but distant ..T. squamosa

The shells of this family are generally large, solid and heavy and the largest of all shells are included here. The ligament is on the external side, and a large byssal gape opens on the anterior dorsal margin and its inner wall is crenulated. The surface is strongly folded by stout ribs often bearing scaly processes, and interspaces between them are sculptured by thinner radial ribs. The cardinal and posterior lateral teeth are present. The posterior muscle scar is placed at the center of the inner surface and the anterior muscle scar is absent. The larger shells reach over four feet in length.
Shell is equivalve, thick, heavy and often very large, with strongly scalloped free margins, inequilateral. Umbones are ventral in position, pointing posteriorly. Free margins of the valves dorsal most in position. Byssal gape is generally well developed, internally plicate, near the umbones. Outer surface of shell with strong radial folds which may be fluted, ribbed or with transverse scales. Ligament is external, set in a groove of anteroventral margin. Hinge with a single, ridge-like cardinal tooth in each valve, 1 lamellar lateral tooth in left valve, and 2 lateral teeth in right valve. Interior of shell is porcelaneous. A single, large and rounded (posterior) adductor muscle scar, associated with a generally large posterior pedal retractor scar, both of them submedian in position. Anterior pedal retractor scar is small, on superior surface of the cardinal tooth. Pallial line without a sinus. Internal margins often more or less crenulated. ${ }^{1-5}$

\section{Tridacna crocea Lamarck, I 8 I 9}

\section{Crocus giant clam}

\section{Frequent synonym: None.}

Shell characters: Shell is relatively small, inequilateral and strongly inflated in shape, usually triangular-ovate in outline. The umbo is located rather anteriorly, and the long posterior dorsal margin has a large byssal opening. The surface bears several stout ribs with narrow interspaces between them. The ribs usually have no scales, but are sometimes scaled near the margin. Exterior of shell colour is greyish white, often suffused with yellow or pinkish orange and frequently encrusted with marine growths near dorsal margins of valves, but clean and nearly smooth ventrally. Interior porcelaneous white, sometimes with yellow to orange hues on margins. Dorsally exposed mantle area of living specimens often brightly coloured and variable in pattern and colour, including green, blue, purple, brown, and orange.

Habitat and fisheries: Deeply burrowed in coral masses of reef flats and coral head, with the free valve margins nearly flush with the substrate's surface. In very shallow water to a depth of about $20 \mathrm{~m}$ (when the water is clear). Collected for food and shell trade. To remove the clam, the coral must be broken and the stout byssus undercut.

Distribution: Tropical eastern Indian Ocean to western Pacific, from Andaman Islands to Fiji Islands; north to Japan and south to New Caledonia and Queensland.

Locality: Pearl I., Kathit I., Ponenyat Gyaing, Kyauk pone gyi hmaw.

\section{T. gigas (Linnaeus, I 758)}

\section{Giant clam}

Frequent synonym: None.

Shell characters: Shell is very thick and heavy, reaching an extremely large size, moderately to strongly inflate and rather equilateral in shape, subovate to fan-shaped in outline. The umbo is situated near the middle of its dorsal margin. This is the largest of all bivalves' shells with six broad and stout radiating ribs set with closely spaced scales that are overlapped towards the ventral margin. Exterior of shell colour is off-white, often strongly encrusted with marine growths. Interior porcelaneous white. Dorsally exposed mantle area of living specimens yellowish brown to olive green, with numerous, small, brilliant blue-green rings. 
Habitat and fisheries: On sand, in coral-reef areas, from depths of 2 to $20 \mathrm{~m}$. Exploited for its meat and shell, this species has recently become nearly extinct within an important part of its range, due to over collecting. Trials of aquaculture under progress for the restocking of reefs and local farming.

Distribution: Eastern Indian Ocean and tropical western Pacific, from southwestern Myanmar and western Indonesia to Micronesia and eastern Melanesia; north to southern Japan and south to Queensland and New Caledonia.

Locality: Pearl I., Ponenyat Gyaing.

\section{T. maxima (Röding, I 798)}

\section{Elongate giant clam}

Frequent synonym: Tridacna elongata Lamarck, 1819.

Shell characters: Shell is moderately large and inflated, strongly inequilateral and highly variable in shape, usually elongate-ovate to somewhat triangular in outline. The umbo is located rather posteriorly, so that the anterior dorsal margin is longer than the posterior margin, on which a large byssal gap opens. The surface has about eight very strong, stout ribs, on which large scales are regularly and distantly placed. In addition, thinner radial ribs are found all over the surface, especially distinctly in younger stages. Exterior of shell colour is greyish white, often suffused with yellow or pinkish orange and strongly encrusted with marine growths. Interior porcelaneous white, sometimes with yellow to orange hues on margins. Dorsally exposed mantle area of living specimens often brightly coloured and variable in colour and pattern.

Habitat and fisheries: On reefs, partially embedded in corals. Littoral and shallow water to a depth of $20 \mathrm{~m}$. Collected for food and for the shell trade. Aquaculture trials currently underway.

Distribution: Widespread in the Indo-West Pacific, from East Africa, including Madagascar, the Red Sea and the Persian Gulf to eastern Polynesia; north to Japan and south to New South Wales and Lord Howe Island.

Locality: Thabyu Gyaing, Ponenyat Gyaing, Kwinwine Gyaing and Maung shwe lay Gyaing.

\section{T. squamosa Lamarck, I 8 I 9}

\section{Fluted giant clam}

Frequent synonym: Tridacna scapha (Meuschen, 1787).

Shell characters: Shell is moderately large (attaining $40 \mathrm{~cm}$ in length), moderately compressed (in juveniles) to strongly inflated

Table 2 Some of ecological and environmental parameters of the study areas

\begin{tabular}{|c|c|c|c|c|c|c|}
\hline Locality & $\begin{array}{l}\text { Depth } \\
\text { (m) }\end{array}$ & $\begin{array}{l}\text { Temperature } \\
\left({ }^{\circ} \mathrm{C}\right)\end{array}$ & Size & Abundance & $\begin{array}{l}\text { Sedimentary } \\
\text { environment }\end{array}$ & $\begin{array}{l}\text { Marine organisms } \\
\text { associations }\end{array}$ \\
\hline Pearl I. & 6 & 23 & $\mathrm{~L}$ & C & BS & CR, SG \\
\hline Kathit I. & 9 & 29 & $M-L$ & $\mathrm{R}$ & BS, TS & CR \\
\hline Thabyu Gyaing & 8 & 27 & $M-L$ & $\mathrm{R}$ & TS & CR \\
\hline Ponenyat Gyaing & 4 & 26 & $M-L$ & C & TS & CR, A, SG \\
\hline Kyauk pone gyi hmaw & 7 & 25.7 & M-L & $\mathrm{C}$ & TS & CR, SG \\
\hline
\end{tabular}

(in mature specimens) and nearly equilateral in shape, semicircular in outline. Umbones is situated about mid length of shell or slightly anterior. The surface has five broad and stout radiating ribs, set with large distantly placed, erect scales. Narrow radial ribs are seen between the large ribs. Exterior of shell colour is highly variable, greyish white, often with different hues of orange, yellow, or pink to mauve, and with the blade-like scales commonly of different shades or colour. Interior porcelaneous white, occasionally tinged with orange. Dorsally exposed mantle area of living specimens mottled in various mixes of green, blue, brown, orange, and yellow.

Habitat and fisheries: Attached by a byssus to the surface of coral reefs, usually in moderately protected localities such as reef moats. Littoral and shallow water to a depth of $20 \mathrm{~m}$. Collected for food and the shell trade.

Distribution: Widespread in the Indo-West Pacific, from East Africa, including Madagascar, the Red Sea, but not the Persian Gulf, to eastern Melanesia; north to southern Japan and south to Queensland and New Caledonia.

Locality: Pearl I., Kathit I., Thabyu Gyaing, Ponenyat Gyaing, Kyauk pone gyi hmaw, Kwinwine Gyaing and Maung shwe lay Gyaing.

The Tridacnidae are highly specialized sedentary bivalves, living in clear shallow waters of coral reefs, with the umbones and hinge situated at the underside of the body and the free edge of shell on the upper side. ${ }^{6}$ Depending on the species, they live either unattached in burrows within the corals, or fastened by a strong byssus. T. squamosa and $T$. crocea are commonly found along the Rakhine, Ayeyawady Delta and Taninthayi coasts especially in Myeik Archipelago. T. maxima is found in the Rakhine coast and widely distributed over tropical areas of the Indo-Pacific. T. gigas is rarely found in the Rakhine and Taninthayi coasts. It ranges to Australia and Japan.

The present study documented the distribution of tridacnids in different sedimentary environment; biogenic, terrestrial or combination from the both (Table 2). Two major environmental factors affect the distribution of tridacnids light intensity (related to the depth) and water temperature. The present study draws attention that tridacnids in the Andrew Bay in Rakhine coast are endangered and may be collapse if the anthropogenic activities are continuous.

Natural population of marine shells can be considered as sustainable resources of Myanmar if they are properly exploited. ${ }^{7}$ However, systematic estimates on the quantities of sea shells that can be collected from the shores have not been made in Myanmar's coastal areas. From visual observations and previous data, the sea shells may be of economic potential used as sea food, medicine, cosmetics, decorative materials, jewellery and souvenir shells. 
Table Continued....

\begin{tabular}{|c|c|c|c|c|c|c|}
\hline Locality & $\begin{array}{l}\text { Depth } \\
\text { (m) }\end{array}$ & $\begin{array}{l}\text { Temperature } \\
\left({ }^{\circ} \mathrm{C}\right)\end{array}$ & Size & Abundance & $\begin{array}{l}\text { Sedimentary } \\
\text { environment }\end{array}$ & $\begin{array}{l}\text { Marine organisms } \\
\text { associations }\end{array}$ \\
\hline Kwinwine Gyaing & II & 24.25 & $\mathrm{~L}$ & A & BS & $C R$ \\
\hline Maung shwe lay Gyaing & 5 & 30 & $\mathrm{~L}$ & A & BS & CR \\
\hline
\end{tabular}

Symbols: L, large; M, medium; C, common; R, rare; A, abundant; BS, biogenic sediments;TS, terrestrial sediments; CR, coral reefs; SG, seagrass; A, algae

\section{Conclusion}

The dominance of seashells can be easily recognized in terms of larger population in Andrew Bay. In terms of number of taxa, gastropods are more common than bivalves. Along the Andrew Bay in Rakhine Coastal Region, the most commonly encountered taxa is $T$. maxima. In Pearl I., Ponenyat Gyaing and Kyauk pone gyi hmaw with clean coral reefs areas, a few numbers of giant clams are commonly found. In the Andrew Bay, giant clams can also be established to create the new livelihoods for the people living in coastal areas.

\section{Acknowledgments}

I am indebted to Dr Aung Myat Kyaw Sein, Rector of Mawlamyine University and Dr Mie Mie Sein and Dr San San Aye, Pro-Rectors of Mawlamyine University, for their encouragement and supports in preparing this work. I am very grateful to Dr San Tha Tun, Professor and Head of the Department of Marine Science, Mawlamyine University, for his valuable suggestions and constructive criticisms on this study. I would like to express my sincere thanks to colleagues of Andrew Bay Field Observation Group, Department of Marine Science, Mawlamyine University, for their kindly help me in many ways during field trip. Many thanks go to Daw Lwin Lwin, Retired Lecturer of the Department of Marine Science, Mawlamyine University, for her assistance in preparations of the manuscript. I would like to thank my beloved parents, U Win Maung and Daw Than Than Aye, for their physical, moral and financial supports throughout this study.

\section{Conflicts of interest}

Author declares that there is no conflicts of interest.

\section{References}

1. Copland JW, Lucas JS. Giant clams in Asia and the Pacific. Canberra. Australian Center for International Agricultural Research. 1988. 274 p.

2. Poutiers JM. Gastropods. In: Carpenter KE, Niem VH, editors. FAO Species Identification Guide for Fishery Purposoe thuses. The Living Marine Resources of the Western Central Pacific. Volume 1. Seaweeds, Corals, Bivalves and Gastropods. Food and Agriculture Organization, Rome: 1998. p. 363-649.

3. Mar Lar Myo Sein. Taxonomy and distribution of Burmese marine bivalves. Unpublished MSc Thesis, Department of Zoology, University of Yangon, Yangon. 1982. 325 p.

4. Naung Naung Oo and Lwin Lwin. A Study on the some Marine Molluscs of Andrew Bay in Rakhine State. Unpublished Departmental Research. 2014. p. 1-30.

5. http:// www.marinespecies.org. 2018.

6. Rosewater J. The family Tridacnidae in the Indo-Pacific. Indo-Pac Moll. 1965;1(6):347-393.

7. Soe Thu. Sea shells of Ngapali. University Education Journal. 1970;5(1):317-368. 